\title{
Security and Privacy in Mobile Cloud Computing
}

\author{
C. Anuradha, N.Priya, S.Pothuman, Mary Linda
}

\begin{abstract}
As of late the Smartphone has encountered basic inventive movements yet in the meantime remains a low computational substance. Versatile distributed computing is one of the advancement basic in the present portable condition kept running by utilizing cell phones in cloud condition. Versatile distributed computing is a promising method to manage impediments of cell phones as far as battery utilization and capacity.

Versatile Cloud Computing is the most basic fields with creating age of the present fast web utilizing and Mobile world close-by its uses it needs to goes facing a fragment of the issues. As the data is scattered preparing and getting to it with cell phones all the trade encounters the framework so it is powerless against strike.
\end{abstract}

KEYWORDS: Distributed computing, Mobile distributed computing, versatile distributed computing engineering, security and protection in mcc

\section{INTRODUCTION}

As movements of devices like phones, tablets, PDAs, etc, which are changing into an essential bit of the present human lifestyle and with this world is moving towards Mobile-world.. These gadgets are get essentially increasingly fundamental since the use of convenient web, instigating productive explicit instruments. As the word adaptable it with no other person's information suggest that they are not bound by time and spot, which is the need of the present included individual

Customers of Mobile can get rich experience of different associations from their own one of a kind Mobile applications e.g., I Phone applications, Google applications, and so forth that keep running on the remote servers by techniques for remote systems.

Appropriated figuring offers various focal shows by permitting customers use structure like servers, accumulating, and framework, stages containing middleware organization, OS and programming for application programs shedding the fundamental for customers to get ready for

Revised Manuscript Received on July 22, 2019.

C.Anuradha, Department of CSE, Bharath Institute of Higher Education and Research, Chennai, Tamilnadu, India.

N.Priya, Department of CSE, Bharath Institute of Higher Education and Research, Chennai, India.

S.Pothumani, Department of CSE, Bharath Institute of Higher Education and Research, Chennai, Tamilnadu, India.

Mary Linda, Department of CSE, Bharath Institute of Higher Education and Research, Chennai, Tamilnadu, India. expanding different resources for cutoff and handling power.

.Particularly, asset can be logically included and released depending affiliation demand and with unimportant affiliation effort. As needs be, the openness of disseminated processing organizations in a convenient area, moreover called adaptable appropriated figuring.

Spread enlisting offers different focal demonstrates by allowing clients use structure like servers ,systems, and breaking point, stages containing middleware association, working systems and programming's for application programs taking out the requirement for clients to prepare for getting obvious assets for limit and figuring power.

\section{MATERIALS AND METHODOLOGY}

Kuyoro S. O, et. al. [1] included key security examinations and challenges which are starting at now looked in the $\mathrm{CC}$ security. CC can transform into a pioneer in propelling an ensured, virtual and monetarily reasonable IT game plan later on.

Rajesh Piplode, et. al [2] featured that the distributed computing vulnerabilities, the disseminated registering vulnerabilities, security perils CC faces and showed the security focus on that ought to be cultivated. On one hand, the security-fragile employments of a Cloud enlisting require abnormal state of security on the other hand, CC are naturally frail against security strikes.

M. Durairaj, et.al [3] proposed a novel secure and undeniable distributed computing for portable encryption calculation. This calculation can be utilized to encode the client information in cloud. Since the customer has no control over the data once their session is logged out, the encryption key goes about as the basic affirmation and the amount of existing frameworks used to execute security in cloud. Particular symmetric and uneven computations were used for creating incredible security instrument. Conveyed processing is improving how information development resources and organizations are used and directed, yet the change constantly goes with new issue. In perspective on this review of composing, our work will be extended by making blend of more than one security frameworks as a cross breed advancement for giving convincing security instrument to Mobile distributed computing.

Hoang T. Dinh, et. al [9] gave a review of versatile distributed computing in which its definitions, design, and points of interest have been exhibited. The supported by adaptable dispersed processing including compact exchange,

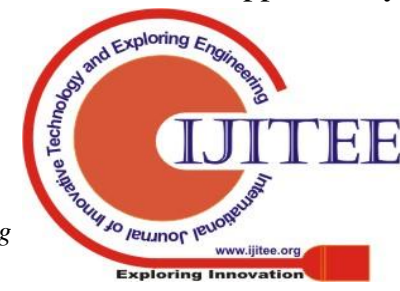


convenient learning, and flexible therapeutic administrations have been discussed which doubtlessly show the genuine nature of the versatile disseminated figuring to a broad assortment of versatile organizations. By then, the issues and related procedures for adaptable circulated processing (i.e., from correspondence and registering sides) have been inspected.

$\mathrm{N}$ Sriram , et. al [10] proposed a novel secure and unquestionable distributed computing for versatile framework utilizing various servers. This system merges the ensured multiparty figuring tradition and the mistook circuit layout for the cryptographically secure pseudorandom number time methodology for Blum et al. This strategy ensures the security of the versatile client's data sources and the delayed consequences of the count, paying little respect to the likelihood that the evaluator interests with everything aside from one of the servers that shared really taking shape of the contorted circuit.

M.Rajendra Prasad, et. al [11] demonstrated the Mobile Cloud Computing will give a full business condition to applications, giving an immediate framework to littler fashioners to change their affiliations correspondingly as new courses to promote. Frantically, Mobile Cloud Computing will decrease the business and explicit anomaly that has so far damage up being a deterrent to pivotal joint exertion between application providers and chairmen on a general scale.

\section{A. Appropriated registering}

Appropriated preparing is a kind of electronic selecting that gives shared PC preparing assets and information to PCs and assorted contraptions on intrigue.It is a model for engaging all inclusive, on-demand access to a common pool of configurable handling resources (e.g., PC systems, servers, stockpiling, applications and services)[1]

Cloud Service is arranged into three conveyance models

1. Software as a Service(SaaS)

2. Platform as a Service(PaaS)

3. Infrastructure as a Service(IaaS)

Software as a service (SaaS):

The supplier permit the client just to utilize its applications eg Google, Google Docs, Facebook, Twitter, Yahoo

Platform as a Service (PaaS):

Application Development, Decision Support, Web Streaming

Eg Google Apps Engine (java/python), Microsoft Window AzureInfrastructure as a Service(IaaS):

Offers end clients direct access to arranging, amassing, and other getting ready assets over the system.

It gives virtual servers entrancing IP zones and squares of cutoff on interest Examples of IaaS join Amazon Elastic Compute Cloud (EC2), Joyent, Rackspace, and IBM Computing on Demand.

\section{B. Cloud Computing}

Versatility has changed into a famous word and quickly developing part in the present taking care of zone.
An amazing improvement has showed up in the movement of cell phones, for example, Smartphone, PDA, and workstations with an assortment of adaptable enrolling, systems association and security impels.

Moreover, with the progress of remote improvement and web it winds up being fundamentally less troublesome and not obliged by the specific office or home or affiliations.

Thusly, a consistently expanding number of people have recognized those mobile phones and offers support to climb in the development of flexible handling [2].

\section{Mobile Cloud Computing (Mcc)}

Versatile Cloud Computing (MCC) is the mix of circulated processing, convenient enlisting and remote structures to pass on rich computational points of interest for compact customers, compose executive, and besides appropriated registering suppliers.

An all out focal point of Mobile appropriated enrolling is to engage execution of rich adaptable applications on an a lot of PDAs, with a rich client experience.

\section{MCC ARCHITECTURE}

In MCC, there are four sorts of cloud-based assets, to be specific far off stationary mists, proximate stable figuring elements, proximate portable processing elements, and half and half (mix of the other three model).

Goliath mists, for instance, Amazon EC2 are the far off fixed gatherings while cloudlet or surrogates are individual from proximate fixed processing substances.

cell phones, tablets, handheld contraptions, and wearable processing gadgets are a piece of the third gathering of cloud-based assets which is proximate portable registering elements.

\section{RESULTS AND DISCUSSIONS}

As Mobile Cloud Computing is mix of portable registering and distributed computing, security peril in versatile processing is acquired from distributed computing. Portable Cloud Computing experiences following danger.

- In Mobile Cloud Computing, the client does not know where their information is put away. So the client has no power over the area of information.

In perspective on physical mischief of cloud server, loss of encoding key because of vindictive insider, danger of information lose may emerge.

- When cloud supplier benefits various clients, defect in encryption calculation can prompt unapproved access to one's information.

- As per administrative consistence cloud supplier needs to keep up required security level.

- User stores and exchange individual data and corporate information while utilizing versatile applications like online installment and 
interpersonal organizations that can be an assailant's new target.

\section{CONCLUSION}

In this area, distinctive kinds of conceivable assaults in MCC are considered.

- SQL Injection Attack: In this kind of strike a harmful code is inserted into a standard SQL code.

Along these lines the aggressors get unapproved access to a database and can get to sensitive data [3].

- Browser Security: Every customer utilizes program to send the data on system.

The program utilizes SSL innovation to encode client's personality and accreditations. Be that as it may, programmers from the delegate host may obtain these certifications by the utilization of sniffing bundles introduced on the go-between host[4] .

\section{REFERENCES}

[1] Kumaravel A., Rangarajan K.,Algorithm for automaton specification for exploring dynamic labyrinths,Indian Journal of Science and Technology,V-6,I-SUPPL5,PP-4554-4559,Y-2013

[2] P. Kavitha, S. Prabakaran "A Novel Hybrid Segmentation Method with Particle Swarm Optimization and Fuzzy C-Mean Based On Partitioning the Image for Detecting Lung Cancer" International Journal of Engineering and Advanced Technology (IJEAT) ISSN 2249-8958, Volume-8 Issue-5, June 2019

[3] Kumaravel A., Meetei O.N.,An application of non-uniform cellular automata for efficient cryptography,2013 IEEE Conference on Information and Communication Technologies, ICT 2013,V-,I-,PP-1200-1205,Y-2013

[4] Kumarave A., Rangarajan K.,Routing alogrithm over semi-regular tessellations,2013 IEEE Conference on Information and Communication Technologies, ICT 2013,V-,I-,PP-1180-1184,Y-2013

[5] P. Kavitha, S. Prabakaran "Designing a Feature Vector for Statistical Texture Analysis of Brain Tumor" International Journal of Engineering and Advanced Technology (IJEAT) ISSN: 2249-8958, Volume-8 Issue-5, June 2019

[6] Dutta P., Kumaravel A.,A novel approach to trust based identification of leaders in social networks, Indian Journal of Science and Technology,V-9,I-10,PP--,Y-2016

[7] Kumaravel A., Dutta P.,Application of Pca for context selection for collaborative filtering,Middle - East Journal of Scientific Research,V-20,I-1,PP-88-93,Y-2014

[8] Kumaravel A., Rangarajan K.,Constructing an automaton for exploring dynamic labyrinths,2012 International Conference on Radar, Communication and Computing, ICRCC 2012,V-,I-,PP-161-165,Y-2012

[9] P. Kavitha, S. Prabakaran "Adaptive Bilateral Filter for Multi-Resolution in Brain Tumor Recognition" International Journal of Innovative Technology and Exploring Engineering (IJITEE) ISSN: 2278-3075, Volume-8 Issue-8 June, 2019

[10] Kumaravel A.,Comparison of two multi-classification approaches for detecting network attacks, World Applied Sciences Journal,V-27,I-11,PP-1461-1465,Y-2013

[11] Tariq J., Kumaravel A.,Construction of cellular automata over hexagonal and triangular tessellations for path planning of multi-robots,2016 IEEE International Conference on Computational Intelligence and Computing Research, ICCIC 2016,V-,I-,PP--,Y-2017

[12] Sudha M., Kumaravel A.,Analysis and measurement of wave guides using poisson method,Indonesian Journal of Electrical Engineering and Computer Science,V-8,I-2,PP-546-548,Y-2017

[13] Ayyappan G., Nalini C., Kumaravel A.,Various approaches of knowledge transfer in academic social network,International Journal of Engineering and Technology,V-,I-,PP-2791-2794,Y-2017

[14] Kaliyamurthie, K.P., Sivaraman, K., Ramesh, S. Imposing patient data privacy in wireless medical sensor networks through homomorphic cryptosystems 2016, Journal of Chemical and
Pharmaceutical Sciences 92.

[15] Kaliyamurthie, K.P., Balasubramanian, P.C. An approach to multi secure to historical malformed documents using integer ripple transfiguration 2016 Journal of Chemical and Pharmaceutical Sciences 9

[16] A.Sangeetha,C.Nalini,"Semantic Ranking based on keywords extractions in the web", International Journal of Engineering \& Technology, 7 (2.6) (2018) 290-292

[17] S.V.GayathiriDevi,C.Nalini,N.Kumar,"An efficient software verification using multi-layered software verification tool "International Journal of Engineering \& Technology, 7(2.21)2018 454-457

[18] C.Nalini,ShwtambariKharabe,"A Comparative Study On Different Techniques Used For Finger - Vein Authentication", International Journal Of Pure And Applied Mathematics, Volume 116 No. 8 2017, 327-333, Issn: 1314-3395

[19] M.S. Vivekanandan and Dr. C. Rajabhushanam, "Enabling Privacy Protection and Content Assurance in Geo-Social Networks", International Journal of Innovative Research in Management Engineering and Technology, Vol 3, Issue 4, pp. 49-55, April 2018.

[20] Dr. C. Rajabhushanam, V. Karthik, and G. Vivek, "Elasticity in Cloud Computing", International Journal of Innovative Research in Management, Engineering and Technology, Vol 3, Issue 4, pp. 104-111, April 2018.

[21] K. Rangaswamy and Dr. C. Rajabhushanamc, "CCN-Based Congestion Control Mechanism In Dynamic Networks", International Journal of Innovative Research in Management, Engineering and Technology, Vol 3, Issue 4, pp. 117-119, April 2018.

[22] Kavitha, R., Nedunchelian, R., "Domain-specific Search engine optimization using healthcare ontology and a neural network backpropagation approach", 2017, Research Journal of Biotechnology, Special Issue 2:157-166

[23] Kavitha, G., Kavitha, R., "An analysis to improve throughput of high-power hubs in mobile ad hoc network" , 2016, Journal of Chemical and Pharmaceutical Sciences, Vol-9, Issue-2: 361-363

[24] Kavitha, G., Kavitha, R., "Dipping interference to supplement throughput in MANET" , 2016, Journal of Chemical and Pharmaceutical Sciences, Vol-9, Issue-2: 357-360

[25] Michael, G., Chandrasekar, A.,'Leader election based malicious detection and response system in MANET using mechanism design approach", Journal of Chemical and Pharmaceutical Sciences(JCPS) Volume 9 Issue 2, April - June 2016

[26] Michael, G., Chandrasekar, A.,"Modeling of detection of camouflaging worm using epidemic dynamic model and power spectral density", Journal of Chemical and Pharmaceutical Sciences(JCPS) Volume 9 Issue 2, April - June 2016

[27] Pothumani, S., Sriram, M., Sridhar, J., Arul Selvan, G., Secure mobile agents communication on intranet,Journal of Chemical and Pharmaceutical Sciences, volume 9, Issue 3, Pg No S32-S35, 2016

[28] Pothumani, S., Sriram, M., Sridhar, Various schemes for database encryption-a survey, Journal of Chemical and Pharmaceutical Sciences, volume 9, Issue 3, Pg NoS103-S106, 2016

[29] Pothumani, S., Sriram, M., Sridhar, A novel economic framework for cloud and grid computing, Journal of Chemical and Pharmaceutical Sciences, volume 9, Issue 3, Pg No S29-S31, 2016

[30] Priya, N., Sridhar, J., Sriram, M. "Ecommerce Transaction Security Challenges and Prevention Methods- New Approach” 2016 ,Journa of Chemical and Pharmaceutical Sciences, JCPS Volume 9 Issue 3.page no:S66-S68

[31] Priya, N.,Sridhar,J.,Sriram, M."Vehicular cloud computing security issues and solutions" Journal of Chemical and Pharmaceutical Sciences(JCPS) Volume 9 Issue 2, April - June 2016

[32]

[33] Priya, N., Sridhar, J., Sriram, M. "Mobile large data storage security in cloud computing environment-a new approach" JCPS Volume 9 Issue 2. April - June 2016

[34] Anuradha.C, Khanna.V, "Improving network performance and security in WSN using decentralized hypothesis testing "Journal of Chemical and Pharmaceutical Sciences(JCPS) Volume 9 Issue 2, April - June 2016 .

[35] Anuradha.C, Khanna.V, "A novel gsm based control for e-devices" Journal of Chemical and Pharmaceutical Sciences(JCPS) Volume 9 Issue 2, April - June 2016

[36] Anuradha.C, Khanna.V, "Secured privacy preserving sharing and data integration in mobile web environments " 
Journal of Chemical and Pharmaceutical Sciences(JCPS) Volume 9 Issue 2, April - June 2016.

[37] Sundarraj, B., Kaliyamurthie, K.P. Social network analysis for decisive the ultimate classification from the ensemble to boost accuracy rates 2016 International Journal of Pharmacy and Technology 8

[38] Sundarraj, B., Kaliyamurthie, K.P. A content-based spam filtering approach victimisation artificial neural networks 2016 International Journal of Pharmacy and Technology 83.

[39] Sundarraj, B., Kaliyamurthie, K.P. Remote sensing imaging for satellite image segmentation 2016 International Journal of Pharmacy and Technology 83.

[40] Sivaraman, K., Senthil, M. Intuitive driver proxy control using artificial intelligence 2016 International Journal of Pharmacy and Technology 84.

[41] Sivaraman, K., Kaliyamurthie, K.P. Cloud computing in mobile technology 2016 Journal of Chemical and Pharmaceutical Sciences 92.

[42] Sivaraman, K., Khanna, V. Implementation of an extension for browser to detect vulnerable elements on web pages and avoid click jacking 2016 Journal of Chemical and Pharmaceutical Sciences 92

\section{AUTHORS PROFILE}

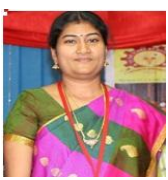

C.Anuradha, Assistant Professor, Department of Computer Science \& Engineering, Bharath Institute of Higher Education and Research, Chennai, India

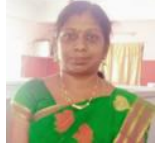

N.Priya, Assistant Professor, Department of Computer Science \& Engineering, Bharath Institute of Higher Education and Research, Chennai, India

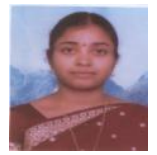

S. Pothumani, Assistant Professor, Department of Computer Science \& Engineering, Bharath Institute of Higher Education and Research, Chennai, India

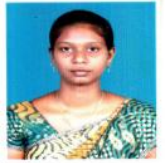

Mary Linda, Assistant Professor, Department of Computer Science \& Engineering, Bharath Institute of Higher Education and Research, Chennai, India 